\title{
INFLUENCE OF THE MANIPULATION TECHNIQUE OF ACRYLIC RESIN ON MECHANICAL STRENGTH OF ORTHODONTIC PLATES
}

\author{
INFLUENCIA DA TÉCNICA DE MANIPULAÇÃO DE RESINA ACRILICA SOBRE A \\ RESISTENCIA MECANICA DE PLACAS ORTODONTICAS
}

\section{Matheus Melo PITHON ${ }^{1}$; Rogério LACERDA-SANTOS ${ }^{2}$; Nathalia SOARES ${ }^{3}$; Davi Novaes Ladeia FOGAÇA ${ }^{4}$; William Soares da SILVA ${ }^{5}$; Luciano Brito RODRIGUES ${ }^{5}$; Raildo Silva COQUEIRO ${ }^{6}$}

1. Professor, Department of Orthodontics, State University of Southwest Bahia, Jéquie, Bahia, Brazil. matheuspithon@gmail.com; 2. Professor, Department of Dentistry, Dental School, Federal University of Juiz de Fora, Governador Valadares, MG, Brazil. lacerdaorto@ hotmail.com; 3. Student of Dentistry, Department of Orthodontics, State University of Southwest Bahia, Jéquie, Bahia, Brazil; 4. Professor, Department of Food Engineering, Federal Institute of Education, Science and Technology of Bahia, Itapetinga, Bahia, Brazil; 5. Professor, Department of Food Engineering, State University of Southwest Bahia, Jéquie, Bahia, Brazil; 6. Professor, Department of Epidemiology, State University of Southwest Bahia, Jéquie, Bahia, Brazil.

\begin{abstract}
The focus of this study was to test the fracture resistance of upper arch dental retainers, made by two different manipulation techniques of acrylic resin. 84 plates Wraparound type retainers were made by two different manipulation techniques forming two groups $(\mathrm{n}=42)$ : Group 1 (Addition Technique) and Group 2 (Pressing Technique). All the retainers were duly shaped in $U$ form with the aid of standardized plaster cast models. During the confection process the standardizing of the retainers was conducted carefully regarding their thickness and dimensions with the aid of a gauge and a straight caliper. After confection they remained immersed in water for 24 hours at $37^{\circ} \mathrm{C}$. Next, they were tested through mechanical compression until fracture in a universal mechanical testing machine. Data were analyzed by Student's t test. The significance level was set at $5 \%(\alpha=0.05)$. It was found that the average was of $79.12 \mathrm{~N}$ for Group 1 and of $77.07 \mathrm{~N}$ for Group 2 with a standard deviation of $17.30 \mathrm{~N}$ and 16.31, respectively, showing that there is no significant difference in resistance for the retainers when made through any of the two methods $(P=0.788)$. The addition and pressure techniques of acrylic resin do not influence the resistance to compression of the upper dental retainers.
\end{abstract}

KEYWORDS: Acrylic resin. Orthodontics. Mechanical Strength.

\section{INTRODUCTION}

In dentistry, the use of acrylic resin or poly methyl methacrylate (PMMA) is common among professionals, especially by orthodontists in the confection of several orthodontic devices such as space maintainers, reclaimers and dental retainers among others (SANTOS et al., 2013).

Chemically activated resin is formed from the liquid, non polymerized methyl methacrylate and powder, which consists predominantly of prepolymerized spheres of poly (methyl methacrylate), that, when mixed in the correct ratio, form a malleable mass with convenient physical properties (BAKER et al., 1988). Manipulation methods described in literature for these materials are addition, wherein the polymer is incrementally saturated with its monomer and the pressing method, where powder and liquid are mixed in a ratio recommended by the manufacturer in a single event, in a 3:1 ratio of powder and liquid, respectively (BAKER et al., 1988; FALTERMEIER et al., 2007; BARLIN et al., 2011). In the technique that the polymer is incrementally saturated with its monomer has the advantage of increased working time and therefore less likely to error in the confection of the plate. On the other hand, it has been questioned as disadvantage which the increase of the amount of monomer used in the confection of the plate could compromise the polymerization reaction (FILHO et al., 2007) and consequently the physical properties of the material changed, besides of their characteristics of cytotoxicity (LEE et al., 2002; FALTERMEIER et al., 2007; GAURAV et al., 2008; ÖZTÜRK et al., 2011).

The acrylic resin can easily fracture due to its low resistance to impact, low flexural strength or low fatigue strength (OLIVEIRA; PANZERI, 2004). Orthodontic appliances tend to fracture due to both occlusive forces and presence of metallic wires which promote dental movement because it suffers some deformation during placement and removal, thus leading to fatigue on the acrylic resin (RANTALA et al., 2003). Thus, the proposal of the authors of this study was to evaluate whether the manipulation techniques of acrylic resin for the fabrication of dental retainers influence the resistance of these devices. 


\section{MATERIAL AND METHODS}

For this study, a single plaster model of a normal occlusion of the maxillary arch was fabricated as aid, delimited with wax seven (Asfer, São Caetano do Sul, SP, Brazil) at the soft palate, cervical and palatal areas of all teeth. From this duly delimited model, several plaster model copies were made in order to achieve a " $U$ " form in all the retainers.

For the confection of the retainers, auto polymerizing acrylic resin (Clássico Ltda, São Paulo, SP, Brazil) was used, where the liquid contained 98\% monomer MMA toluidine, and PMMA powder, ethyl acrylate and benzoyl peroxide.

Prior to acrylization, eighty-four vestibular arches in 0.7 orthodontic wire (Dental Morelli, São Paulo-SP, Brazil) were bent and adapted to the models with the aid of utility wax (Technew, Rio de Janeiro, RJ, Brazil). Next, the model was isolated with plaster (SSWhite Ltda, Rio de Janeiro, RJ, Brazil) followed by the proper acrylization.

The samples were prepared by two manipulation methods forming two groups; 1 addition technique, in which powder and liquid were inserted incrementally using a 3:1.05 powder/liquid ratio to cover the entire wanted area besides forming a translucent layer and, to terminate, all excesses were removed. Group 2 - pressing technique, where the dosing of the powder and liquid was established by the manufacturer himself, in a 3:1 powder/liquid ratio, respectively, which were mixed in a covered
PITHON, M. M. et al.

"paladon" glass pot until the mass got to the plastic phase. Next, the resin was pressed by two glass plates suitably isolated and then adjusted to the plaster models adequately insulated. After a full outline of the resin on the models, the excesses were removed with a Lecron type spatula (SSWhite Ltda, Rio de Janeiro, RJ, Brazil).

After preparation, all the retainers were placed in a bubble eliminator orthodontic pressure cooker at a 20 pounds pressure for 15 minutes, to remove the bubbles.

A MaxiCut drill (Wilcos Meisinger, Petrópolis, RJ, Brazil), a gauge caliper (Golgran Iwanson, São Paulo, SP, Brazil), a straight caliper (Mitutoyo, Santo Amaro, SP, Brazil) and a dermographic pencil (Mitsubishi Pencil Co., Shinagawa-ku, Tokyo, Japan) for identification marks were used to standardize and adjusting the size and thickness of resin plates. The final dimensions of all retainers were $1.5 \mathrm{~mm}$ thickness across overall plate extension, $1.8 \mathrm{~cm}$ lateral height, $2.5 \mathrm{~cm}$ of height in the area of palatine corrugation and $4.0 \mathrm{~cm}$ total length of the plate. The samples were mechanically polished using pumice and water sandpaper, granulation 600 and 1200. Throughout the fabrication process, the plates were kept immersed in water at $37{ }^{\circ} \mathrm{C}$.

After 24 hours, the plates were taken individually (Figure 1A-B) to a universal mechanical testing machine (Oswaldo Filizzola, São Paulo, SP, Brazil) to evaluate the compressive strength $(\mathrm{N})$.

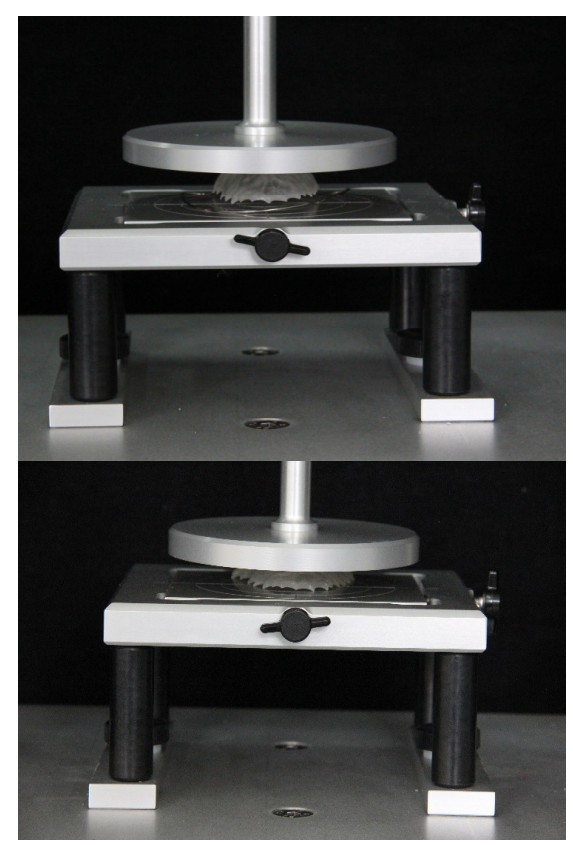

Figure 1. A) Orthodontic plate before of the compression test, and B) Orthodontic plate being submitted to the compression test in the Universal Mechanical Testing Machine. 


\section{Statistical procedure}

For descriptive analysis of the force values (N) means and standard deviations were calculated, with the differences between the methods (pressing vs. addition) being compared by the Student's t-test for independent samples, after verification of the data's normality using the Kolmogorov-Smirnov test. The significance level was set at 5\% $(\alpha=0.05)$. Data were tabulated and analyzed using the statistical program BioEstat (version 5.0, Belém, PA, Brazil).

\section{RESULTS}

During this process, the compressive force was measured at the time of fracture for each plate individually, creating an average for the two tested groups. Group 1 - addition technique - variance average was $79.12 \mathrm{~N}$ and Group 2 - pressing technique - average $77.07 \mathrm{~N}$. The standard deviation
PITHON, M. M. et al.

of Group 1 was $17.30 \mathrm{~N}$ and of Group 2 of $16.31 \mathrm{~N}$. These data show that there was no statistically significant difference between the two tested methods ( $\mathrm{P}=0.788)$.

With respect the location of the sample fracture. In the group 1, $90 \%$ of the samples had vertical fracture in the lateral height and $10 \%$ had a combination of vertical fracture in the lateral height and incipient cracks in the corrugated surface of palate. In group $2,85 \%$ of the samples had vertical fracture in the lateral height, $5 \%$ had a combination of vertical fracture in the lateral height and incipient cracks in the corrugated surface of palate, and 10\% had longitudinal fractures in the lateral height.

Figure 2 shows the mean values of the measured force at the time of fracture, according to the method of handling the resin. Data show no significant differences in strength between the pressing method and the addition method.

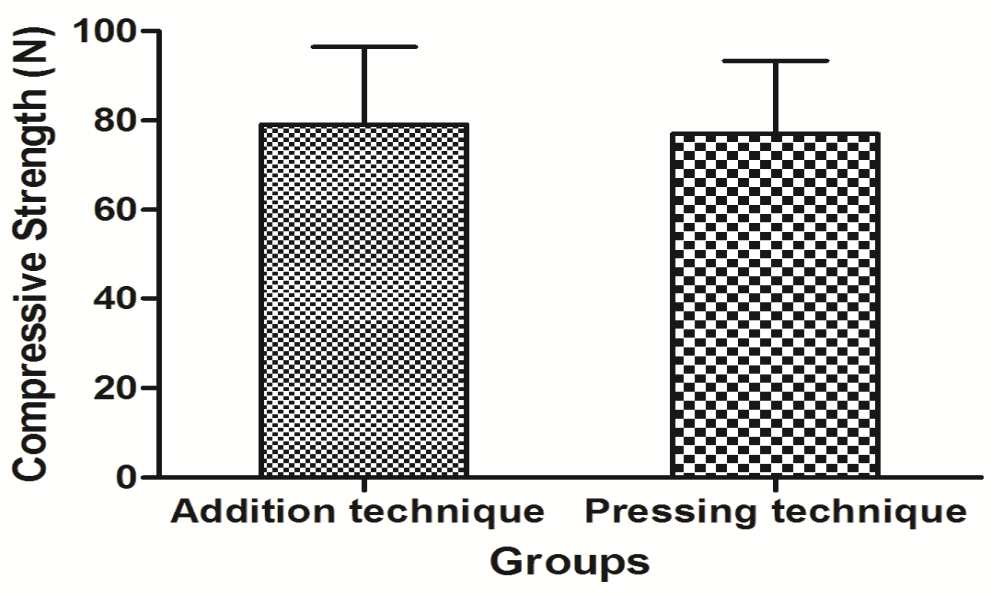

Figure 2. Mean values \pm standard deviations from the measured strength of the fracture time according to the method of handling the acrylic resin.

\section{DISCUSSION}

The manipulation process of acrylic resin, although widely used, is little explored in dentistry. In the results obtained from this study showed no statistical difference in resistance between the two existing methods of manipulation. These results are of great clinical importance given that there is still doubt about the best technique among professionals. In study (GONÇALVES et al., 2008) on the resistance of acrylic resin in phosphate incorporation in addition to the monomer, concluded that resistance was not affected with the addition of this component, results that corroborate the findings of this study.

Some studies have shown that the polishing techniques of acrylic resin can influence its mechanical properties by increasing the ratio of monomers, especially when the polishing is chemical (MCCABE; BASKER, 1976; STAFFORD; BROOKS, 1985; KEDJANURE et al., 1999; RANTALA et al., 2003; RUIZ-GENAO et al., 2003; FALTERMEIER et al., 2007; SANTOS et al., 2013). This high amount of residual monomer 
increases the absorption of water, thus reducing the mechanical properties of the resin, since water acts as a plasticizing agent penetrating the spaces between the polymer chains and decreasing secondary chemical bonds, such as Van der Waals force (MELLO et al., 2003; GONÇALVES et al., 2008).

In tests evaluating resin cytotoxicity using denture bases of the material, it was found that the polymer and monomer proportion influences on the cytotoxicity of the final product (TACIR et al., 2006). However, nothing was mentioned about the mechanical characteristics of these materials, object of this study. Study (ÖZTÜRK et al., 2011) that evaluated the cytotoxicity of three orthodontic acrylics and two different manipulation techniques, concluded that the time increased the cytotoxicity of the tested materials, but there was no significant difference between the two methods of manipulation. A similar result occurred in the present study where no resistance changes occurred when the handling method was changed.

It is known that the presence of residual monomer may influence on various factors and that there is relevance when monomer and polymer ratio is considered (BAKER et al., 1988; TACIR et al., 2006). Nevertheless, in the present study, despite the addition technique to have used $5 \%$ more monomer, it was observed that this factor did not influence the strength of the compression plates of retention when compared the pressure technique. It is suggested that occur some evaporation of monomer during the manufacture of the plate, which would make the addition technique similar the of pressure technique by the amount of the similar final monomer. The location of fractures of the samples were also similar, $90 \%$ and $85 \%$ of the samples had vertical fracture in the lateral height for the groups of the addition and pressure techniques, respectively.

Study (FALTERMEIER et al., 2007) on the effectiveness of different pre-polymerase methods on the properties of the acrylic resins of removable orthodontic appliances, found that heat, when used as a secondary curing method, decreases the water absorption of the material, improving its properties.

Nowadays, it is very common to use compounds to provide greater strength to the resin and some studies show that the addition of fiberglass can increase resistance to rupture and flexion of the material (URBAN et al., 2007; TELLES et al., 2009). When evaluating the flexural strength of orthodontic acrylic resins from two different manufacturers, comparing pigmented resins with colorless ones, concluded that the pigments have no effect on the decrease of acrylic resin flexural strength (TELLES et al., 2009).

In Dentistry, the two evaluated manipulation methods are quite used by professionals and according to the results of this study they show good resistance of the devices. More studies are necessary now, evaluating other aspects such as the retention of microorganisms, genotoxicity, among others.

\section{CONCLUSION}

It can be concluded with the execution of this study, that the two resin manipulation techniques evaluated, addition technique and pressing technique did not alter the compressive strength of orthodontic retainer plates.

RESUMO: O foco deste estudo foi testar a resistência à fratura de retentores odontológicos do arco superior, feito por duas diferentes técnicas de manipulação de resina acrílica. 84 placas de retentores tipo Wraparound foram feitas por duas diferentes técnicas de manipulação que formam dois grupos $(n=42)$ : Grupo 1 (técnica de adição) e Grupo 2 (técnica de prensagem). Todos os retentores foram devidamente moldados em forma de U, com o auxílio de modelos de gesso padronizados. Durante o processo de confecção a padronização dos retentores foi conduzida cuidadosamente em relação à sua espessura e dimensões, com o auxílio de um medidor e um compasso de calibre linear. Após a confecção eles permaneceram imersos em água por 24 horas a $37^{\circ} \mathrm{C}$. Em seguida, eles foram testados através de compressão mecânica até a fratura em uma máquina universal de ensaios mecânicos. Os dados foram analisados pelo teste t de Student. O nível de significância foi de $5 \%(\alpha=0,05)$. Verificou-se que a média foi de 79,12 N para o Grupo 1 e de 77,07 N para o Grupo 2, com um desvio padrão de 17,30 N e 16,31, respectivamente, indicando que não há diferença significativa na resistência para os retentores, quando feita através de qualquer um dos dois métodos $(\mathrm{P}=0,788)$. As técnicas de adição e pressão de resina acrílica não influenciaram a resistência à compressão dos retentores dentárias superiores.

PALAVRAS-CHAVE: Resina Acrílica. Ortodontia. Resistência Mecânica. 


\section{REFERENCES}

BAKER, S.; BROOKS, S. C.; WALKER, D. M. The release of residual monomeric methyl methacrylate from acrylic appliances in the human mouth: an assay for monomer in saliva. J. Dent. Res., Chicago, v. 67, n. 10, p. 1295-1299, Oct. 1988.

BARLIN, S.; SMITH, R.; REED, R.; SANDY, J.; IRELAND, A. J. A retrospective randomized double-blind comparison study of the effectiveness of Hawley vs vacuum-formed retainers. Angle Orthod., Appleton, v. 81, n. 3, p. 404-409, May. 2011.

FALTERMEIER, A.; ROSENTRITT, M.; MÜSSIG, D. Acrylic removable appliances: Comparative evaluation of different postpolymerization methods. Am. J. Orthod. Dentofacial Orthop., St. Louis, v. 131, n. 3, p. 301.e16-22, Mar. 2007.

FILHO, R. R.; PAULA, L. V.; COSTA, V. C.; SERAIDARIAN, P. I. Evaluation of residual monomer in autopolymerizing acrylic resins: spectroscopy analysis. Rev. Dent. Press Ortod. Ortop. Facial., Maringá, v. 12, n. 2, p. 96-104, Mar-Apr. 2007.

GAURAV, P.; DAVID, W. B.; VIRENDRA, B. D.; PERIATHAMBY, A. R.; SAMEER, K. R.; GUNJAN, D.; et al. Effect of phosphate group addition on the properties of denture base resins. J. Prosthet. Dent., St. Louis, v. 100, n. 4, p. 302-308, Oct. 2008.

GONÇALVES, T. S.; MENEZES, L. M.; SILVA, L. E. A. Residual monomer of autopolymerized acrylic resin according to different manipulation and polishing methods. Angle Orthod., Appleton, v. 78, n. 4, p. 722-727, Jul. 2008.

GONÇALVES, T. S.; SPOHR, A. M.; SOUZA, R. M.; MENEZES, L. M. Surface roughness of auto polymerized acrylic resin according to different manipulation and polishing methods. Angle Orthod., Appleton, v. 78, n. 5, p. 931-934, Sep. 2008.

KEDJANURE, U.; CHAROENOWORALUK, N.; KOONTONGKAEW, S. Realese of methyl methacrylate from heat-cured and autopolymerized resins: Cytotoxicity testing related to residual monomer. Aust. Dent. J., Sydney, v. 44, n. 1, p. 25-30, Jan. 1999.

LEE, S. Y.; LAI, Y. L.; HSU, T. S. Influence of polymerization conditions on monomer elution and microhardness of autopolymerized polymelhyl methacrylate resin. Eur. J. Oral Sci. Copenhagen, v. 110, n. 2, p. 179-183, Apr. 2002. http://dx.doi.org/10.1034/j.1600-0722.2002.11232.x

MCCABE, J. F.; BASKER, R. M. Tissue sensitivity to acrylic resin. A method of measuring the residual monomer content and its clinical application. Br. Dent. J. London, v. 140, n. 10, p. 347-350, May. 1976.

MELLO, J. A. N.; BRAUN, K. O.; RACHED, R. N.; DEL BEL CURY, A. A. Reducing the negative effects of chemical polishing in acrylic resins by use of an additional cycle of polymerization. J. Prosthet. Dent., St. Louis, v. 89, n. 6, p. 598-602, Jun. 2003.

OLIVEIRA, A. G.; PANZERI, H. Flexural and fatigue strength of chemically activated resin in association with a hybrid fibre. Biosci. J. Uberlandia, v. 20, n. 2, p. 103-12, May-Aug. 2004.

ÖZTÜRK, F.; MALKOC, S.; ERSÖZ, M.; HAKKI, S. S.; BOZKURT, B. S. Real- time cell analysis of the components of orthodontic acrylic materials on gingival fibroblasts. Am. J. Orthod. Dentofacial Orthop., St. Louis, v. 140, n. 5, p. e243-9, Nov. 2011.

RANTALA, L. I.; LASTUMÄKI, T. M.; PELTOMÄKI, T.; VALLITTU, P. K. Fatigue resistance of removable orthodontic appliance reinforced with glass fibre weave. J. Oral Rehabil., Oxford, v. 30, n. 5, p. 501-6, May.2003. 
RUIZ-GENAO, D. P.; VEGA, M. J. M.; SANCHEZ, P. J.; GARCIA-DIEZ, A. Labial edema due to an acrylic dental prosthesis. Contact Dermatitis. Copenhagen, v. 48, n. 5, p. 273-274, May. 2003.

SANTOS, R. L.; PITHON, M. M.; CARVALHO, F. G.; RAMOS, A. A. S.; ROMANOS, M. T. V. Mechanical and biological properties of acrylic resins manipulated and polished by different methods. Braz. Dental J. Ribeirão Preto, v. 24, n. 5, p. 492-497, Sep-Oct. 2013.

STAFFORD, G. D.; BROOKS, S. C. The loss of residual monomer from acrylic orthodontic resins. Dent. Mater. Copenhagen, v. 1, n. 4, p.135-138, Aug. 1985. http://dx.doi.org/10.1016/S0109-5641(85)80005-1

TACIR, I. H.; KAMA, J. D.; ZORTUK, M.; ESKIMEZ, S. Flexural properties of glass fibre reinforced acrylic resin polymers. Aust. Dent. J. Sydney, v. 51, n. 1, p. 52-56, May. 2006.

TELLES, V.; BRITO, R. M. F.; JURACH, E. M.; NOJIMA, L. I. Assessment of flexural strength of two selfcuring acrylic resins containing pigment. Braz. J. Oral Sci. Campinas, v. 8, n. 3, p. 137-140, Jul. 2009.

URBAN, V. M.; MACHADO, A. L.; OLIVEIRA, R. V.; VERGANI, C. E.; PAVARINA, A. C.; CASS, Q. B. Residual monomer of reline acrylic resins: Effect of water-bath and microwave post-polymerization treatments. Dental Mater. Copenhagen, v. 23, n. 3, p. 363-368, Mar. 2007. http://dx.doi.org/10.1016/j.dental.2006.01.021 